\title{
Ash dieback and contributing factors of forest weakening in provenance tests in the Sumy region
}

\author{
Valentyna Meshkova $^{1 *}$, Viacheslav Samoday ${ }^{2}$, Kateryna Davydenko $^{1,3}$ \\ ${ }^{1}$ Ukrainian Research Institute of Forestry \& Forest Melioration, Pushkinska str. 86, Kharkiv, UA - 61024, Ukraine \\ ${ }^{2}$ Krasno Trostyanetske Branch of Ukrainian Research Institute of Forestry and Forest Melioration, \\ Neskuchanska str, 15, Trostyanets, Sumy region, UA - 42600, Ukraine \\ ${ }^{3}$ Swedish University of Agricultural, Department of Forest Mycology and Plant Pathology, Box 7026, \\ SE-75007 Uppsala, Sweden
}

\begin{abstract}
The aim of this study was to evaluate the health condition of Fraxinus excelsior $\mathrm{L}$. in provenance tests, with special focus on ash dieback (ADB), but taking into account also other causes of its decline. The research was carried out in the provenance tests of $F$. excelsior in the forest-steppe part of the Sumy region. ADB symptoms were revealed in all provenance tests. For 2012-2019 the health condition index,ADB incidence and severity increased for all provenances except the Steppe. Collar rot was present in all ash provenances. Fungi species were isolated from the stem parts of ash at all provenances. Hymenoscyphus fraxineus induced longest necrotic lesions following wound inoculation of stems of 7-10-years-old plants of European ash in the forest while inoculation with both Cytospora sp. and Diplodia sp. resulted in smaller necroses. The conclusion from other regions about the coincidence the damage of European ash by ADB and collar rots as well as the coincidence the damage of European ash by collar rot and tree colonization by Hylesinus crenatus (Fabricius, 1787) is supported.
\end{abstract}

Key words: Fraxinus excelsior; collar rot; health condition; incidence; severity

Editor: Bohdan Konôpka

\section{Introduction}

Recently, in many European countries, deterioration of health condition of Fraxinus excelsior L. stands has been registered (Matsiakh \& Kramarets 2014; Goberville et al. 2016; Enderle et al. 2017; Meshkova \& Borysova 2017), which is largely due to the spread of a new invasive pathogen Hymenoscyphus fraxineus (T. Kowalski) Baral, Queloz \& Hosoya (Queloz et al. 2011; Baral et al. 2014; Gross et al. 2014). The presence of this fungus in the symptomatic shoots of European ash (Fraxinus excelsior) from the Sumy region of Ukraine was confirmed by molecular methods (Davydenko et al. 2013b). The occurrence of this pathogen in ash shoots with pronounced symptoms of the disease (necrotic spots on the bark, discoloration) was statistically proven. For trees affected, the gradual death of crowns, the presence of necrotic spots on the bark of shoots, leaves and stems, discoloration of wood and shoots, uneven flowering, and premature fall were registered (Skovsgaard et al. 2010; Metzler et al. 2012; Davydenko \& Meshkova 2017).

Provenance tests with long-term history is a very suitable approach to study many issues, among which is the susceptibility of different provenances to some pathogens (Metzler et al. 2012; Stener 2013; McKinney et al. 2014; Enderle et al. 2015). Such provenance tests of Fraxinus excelsior were created in 1930 under the leadership of prof.V. M. Andreiev in the Sumy region (Davydenko et al. 2013a).

In 2012, inspection of these provenance tests was carried out with assessment of ash dieback (ADB) incidence and severity as well as the health condition for each provenance (Davydenko et al. 2013a). Over the past years, the progressive development of ash dieback has been registered in many sample plots in different regions of Ukraine (Davydenko et al. 2019). Therefore, it was the basis for repeated assessment of ash dieback parameters in the provenance tests in the Sumy region.

The aim of this study was to evaluate the health condition parameters of Fraxinus excelsior in provenance tests, with special focus on ash dieback, but taking into account also other causes of its decline. One aspect of our research on ash dieback was aimed at determining fungi associated with ash trees and the ability of certain fungi to cause necrosis on the shoots of European ash saplings. 


\section{Material and methods}

The research was carried out in the provenance tests of Fraxinus excelsior in the State Enterprise "Trostyanetske Forest Economy" in the forest-steppe part of the Sumy region $\left(50^{\circ} 29^{\prime} 05^{\prime \prime} \mathrm{N} ; 34^{\circ} 57^{\prime} 56^{\prime \prime} \mathrm{E}\right)$.

Within these stands, 5 provenance tests of $F$. excelsior were tested: Poliskyi, Western Forest-Steppe, Right-Bank Forest-Steppe, Left-Bank Forest-Steppe and Steppe.

From each provenance, 50 living trees of European ash were inspected. Besides diameter at breast height (DBH) several parameters of ash health condition were additionally assessed in each provenance test. Social position within the stand was assessed according to Kraft classification (class 1 - predominant trees, class 2 - dominant trees, class 3 - subdominant trees, class 4 - suppressed trees and class 5 - dying trees) (Lech et al. 2020).

Category of tree health condition was evaluated on a range of visual characteristics (crown density and color, the presence and proportion of dead branches in the crown, etc.) according to National scale (Davydenko et al. 2019). Each tree was referred to one of four categories of health condition (1st - healthy; 2nd - weakened; $3 \mathrm{rd}$ - severely weakened; 4 th - drying up). Health condition index ( $\mathrm{HCl}$ ) for each plot was calculated as mean of the health condition categories of studied trees.

The incidence of ash dieback, collar rots, and Hylesinus crenatus (Fabricius, 1787) (Coleoptera: Curculionidae: Scolytinae) galleries was estimated as a proportion of living ash trees with characteristic symptoms within the sample from each provenance.

Severity of ash dieback for each ash tree was estimated by score: 0 points - no symptoms, 1 point - the presence of several indirect symptoms (uneven leafing, single drying of shoots, individual necroses on healthy shoots, drying up to $10 \%$ of branches; 2 points - the presence of these symptoms, drying of more than $10 \%$ and up to $50 \%$ of shoots and branches, formation necrosis, 3 -drying of more than $50 \%$ of the crown, discoloration of wood in the area of necroses, the presence of necroses and drying of leaves, shoots, branches, 4 - damage to $100 \%$ of the crown, the presence of necroses even on green shoots and branches, leaves, stems (Metzler et al. 2012). Severity of ash dieback for each provenance was evaluated as an arithmetic average of all trees scores.

By epicormic shoots, the trees were rated as follow: 0 - absence of epicormic shoots; 1 - sporadic epicormic shoots; 2 - multiple epicormic shoots; 3 - total stem coverage with epicormic shoots (Meshkova \& Borysova 2017). Each stem collar was examined for the presence or absence of stem necroses and signs of wood decay fungi. The score of wood decay severity (collar rots) considered the part of damaged stem circumference: 0 points - absence; 1 point - up to $25 \%$ of circumference; 2 points $-26-50 \%$; 3 points $-51-75 \%$; 4 points - over $75 \%$ of circumference (Davydenko et al. 2019).
Fungal isolation. The wood samples were taken by Haglöf increment borer $10 \mathrm{~cm}$ or over in length from F. excelsior trees randomly. Five samples per each provenance ( 25 samples in total) were packed individually in Falcon tubes, marked and placed into freezer $\left(-20^{\circ} \mathrm{C}\right)$. After surface sterilization in flame, wood samples were placed in Petri dishes containing ca. $30 \mathrm{ml}$ of $3 \%$ malt extract agar medium (MEA) and incubated at room temperature (ca. $21^{\circ} \mathrm{C}$ ) in the dark. Petri dishes were checked daily and outgrowing fungal mycelia were subcultured to new Petri dishes with MEA. Fungal cultures were divided into groups based on their morphology and for species identification representative cultures from each group were subjected to sequencing of the internal transcribed spacer of the fungal ribosomal RNA (ITS rRNA). Isolation of DNA, amplification and sequencing followed methods described by Davydenko \& Meshkova (2017). The thermal cycling was carried out using an Applied Biosystems GeneAmp PCR System 2700 thermal cycler (Foster City, CA, USA): initial denaturation step at $95^{\circ} \mathrm{C}$ for $5 \mathrm{~min}$. was followed by 35 amplification cycles of denaturation at $95^{\circ} \mathrm{C}$ for $30 \mathrm{~s}$, annealing at $55^{\circ} \mathrm{C}$ for $30 \mathrm{~s}$, and extension at $72^{\circ} \mathrm{C}$ for $30 \mathrm{~s}$ and final extension step at $72^{\circ} \mathrm{C}$ for $7 \mathrm{~min}$. Raw sequence data were analyzed using the SeqMan Pro version 10.0 software from DNASTAR package (DNASTAR, Madison, WI, USA). The criteria used for identification were: sequence coverage $>80 \%$; similarity to taxon level $98-100 \%$, similarity to genus level $94-97 \%$. Some fungal species were detected by morphological symptoms (fruit bodies, spores, etc.).

Pathogenicity test. In the inoculation tests carried out in May 2020, the following fungi, considered as putative pathogens, were used: Alternaria alternata (Fr.) Keissl., Didymella macrostoma (Mont.) Qian Chen \& L. Cai, Hymenoscyphus fraxineus, Epicoccum nigrum Link, and Fusarium avenaceum (Fr.) Sacc., Cytospora sp. 15 and Diplodia sp. (for the last two fungi, only genera were identified). The pathogenicity of these fungi to the $F$. excelsior plants was determined in the field experiment. The stems of 7-10-year-old plants growing in the forest were each superficially wounded by removal of bark $(0.5 \mathrm{~cm}$ diameter) with a razor blade in $8 \mathrm{~cm}$ from the shoot tip. A disc cut from a fungal culture was placed on each wound and then covered by Parafilm strip. In the field experiment, five trees per isolate were used ( 35 trees per all fungal species), whereas 10 control plants were inoculated with sterile MEA. Observations of both necrosis and tree condition (crown dieback) were made at weekly intervals for 4 months. The data were expressed as mean lesion length. Re-isolations of the test fungi from all the inoculated plants were attempted by plating material from lesions (if present) or from points of inoculation. The lesion material was taken from sections ca. 5 $\mathrm{mm}$ both above and below each inoculation point. Fungi growing from the material were re-isolated as described in the above procedures for isolation. 
Normality tests, summary statistics, one-way analysis of variance (ANOVA), Tukey HSD test with a significance level of $p<0.05$ were performed. Shapiro-Wilk test has proved the normality of analyzed parameters (ADB, collar rots and H. crenatus incidence and severity, health condition index) when comparing the provenances between each other in 2012 and 2019, and each provenance in 2012 and 2019. Microsoft Excel software and statistical software package PAST: Paleontological Statistics Software Package for Education and Data Analysis (Hammer et al. 2001) were used.

\section{Results}

The results of the 2012 assessment showed that the diameter (30.3-32.1 cm), Kraft class $(2.3-2.6)$ and health condition index (1.8-2.4) of individual provenances did not have statistically significant differences (Table 1 ).

In 2019 assessment, the diameter $(31.1-33.2 \mathrm{~cm})$, Kraft class (2.2-2.6) and health condition index (2.52.8) of individual provenances also did not have statistically significant differences (Table 2).

Statistically significant differences were registered between the provenances in terms of branch dieback and the presence of epicormic shoots (Table 2). The branch dieback was the lowest in the Steppe provenance (5.5\%), which is significantly less than in the other provenances, except for the Western forest-steppe. The highest values of branch dieback were assessed in the Poliskyi and Right-bank forest-steppe provenances (15.3\%), with the maximum values reaching 50\% (Poliskyi).

The prevalence of epicormic shoots ranged from 0.8 points in the Steppe and Left-Bank Forest-Steppe provenances to 1.7 points in the Right-Bank Forest-Steppe. However, Tukey's test showed a significant difference only between Right-Bank Forest-Steppe and two above mentioned provenances $(\mathrm{P}<0.05)$.

In 2019 compared with 2012, the DBH increased in all provenances, and the Kraft class a bit increased only in the Left-bank Forest Steppe and Steppe provenances.
The health condition index significantly increased in 2019 compared with 2012 for all provenances except the Steppe, for average sample from 2.1 to 2.6.

In 2012, ADB incidence was the lowest in the Western Forest-Steppe provenance (25\%), almost twice as high in Poliskyi and Right-bank Forest-Steppe provenance and the highest in the rest provenances (83.3 and $91.7 \%$ in the Left-bank Forest Steppe and Steppe respectively) (Table 3). The differences between these three groups of provenances are significant.

Table 3. Comparison of ADB parameters in Fraxinus excelsior provenance tests in 2012 and 2019.

\begin{tabular}{lcccc}
\hline \multirow{2}{*}{ Provenance } & \multicolumn{2}{c}{ ADB incidence, [\%] \pm SE } & \multicolumn{2}{c}{$\begin{array}{c}\text { ADB severity, } \\
\text { [points] } \pm \text { SE }\end{array}$} \\
\cline { 2 - 5 } & 2012 & 2019 & 2012 & 2019 \\
\hline Poliskyi & $58.3 \pm 6.97 \mathrm{a}$ & $90.0 \pm 6.71 \mathrm{~d}$ & $0.7 \pm 0.09 \mathrm{~b}$ & $1.8 \pm 0.12 \mathrm{~d}$ \\
Western Forest-Steppe & $25.0 \pm 6.12 \mathrm{~b}$ & $75.0 \pm 4.78 \mathrm{e}$ & $0.3 \pm 0.09 \mathrm{a}$ & $1.3 \pm 0.09 \mathrm{c}$ \\
Right-bank Forest Steppe & $58.3 \pm 6.97 \mathrm{a}$ & $70.0 \pm 5.12 \mathrm{ae}$ & $0.7 \pm 0.09 \mathrm{~b}$ & $1.2 \pm 0.12 \mathrm{c}$ \\
Left-bank Forest Steppe & $83.3 \pm 5.27 \mathrm{c}$ & $100.0 \pm 0.00 \mathrm{~d}$ & $0.8 \pm 0.05 \mathrm{~b}$ & $1.8 \pm 0.11 \mathrm{~d}$ \\
Steppe & $91.7 \pm 3.91 \mathrm{c}$ & $75.0 \pm 4.78 \mathrm{ce}$ & $1.4 \pm 0.09 \mathrm{c}$ & $1.3 \pm 0.09 \mathrm{c}$ \\
\hline Total & $63.3 \pm 3.05 \mathrm{a}$ & $82.0 \pm 3.84 \mathrm{~b}$ & $0.8 \pm 0.04 \mathrm{~b}$ & $1.5 \pm 0.10 \mathrm{~d}$ \\
\hline Note: * Means followed by different letters in each column are significantly different at the $95 \%$ \\
confidence level.
\end{tabular}

In 2019 compared to 2012, ADB incidence increased 1.3 times in total, 3 times in the West Forest-Steppe, 1.5 times in Poliskyi and 1.2 times in the Right-bank and Left-bank Forest-Steppe provenances, however, the increase was significant only for three provenances (Table 3). Significance of increase the ADB incidence for Right-bank Forest-Steppe and of its decrease for Steppe provenance was not proved.

In 2012, ADB severity score was the lowest in the Western Forest steppe ( 0.3 points) and the highest in the Steppe provenance (1.4 points) (Table 3$)$. The rest three provenances with ADB severity score $0.7-0.8$ points did not differ significantly among themselves, but were significantly above the minimum and below the maximum value of this parameter.

In 2019, ADB severity score was the lowest in the Right-bank Forest steppe (1.2 points) and didn't differ statistically from Western Forest-Steppe and Steppe (1.3

Table 1. General parameters of Fraxinus excelsior health condition in different provenance tests (2012).

\begin{tabular}{lccc}
\hline Provenance & DBH, $[\mathrm{cm}] \pm$ SE & Kraft class, [points] \pm SE & Health condition index, [points] \pm SE \\
\hline Poliskyi & $30.3 \pm 1.21 \mathrm{a}$ & $2.5 \pm 0.08 \mathrm{a}$ & $1.8 \pm 0.09 \mathrm{a}$ \\
Western Forest-Steppe & $31.1 \pm 1.21 \mathrm{a}$ & $2.5 \pm 0.06 \mathrm{a}$ & $1.8 \pm 0.08 \mathrm{a}$ \\
Right-bank Forest Steppe & $31.3 \pm 1.30 \mathrm{a}$ & $2.6 \pm 0.05 \mathrm{a}$ & $2.0 \pm 0.10 \mathrm{a}$ \\
Left-bank Forest Steppe & $32.1 \pm 1.39 \mathrm{a}$ & $2.3 \pm 0.06 \mathrm{a}$ & $2.4 \pm 0.09 \mathrm{a}$ \\
Steppe & $31.6 \pm 1.23 \mathrm{a}$ & $2.5 \pm 0.07 \mathrm{a}$ & $2.4 \pm 0.09 \mathrm{a}$ \\
\hline Total sample & $31.3 \pm 0.84 \mathrm{a}$ & $2.5 \pm 0.06 \mathrm{a}$ & $2.1 \pm 0.04 \mathrm{a}$ \\
\hline
\end{tabular}

Note: *Means in each column are not significantly different at the $95 \%$ confidence level.

Table 2. General parameters of Fraxinus excelsior health condition in different provenance tests (2019).

\begin{tabular}{|c|c|c|c|c|c|}
\hline Provenance & $\begin{array}{c}\mathrm{DBH}, \\
{[\mathrm{cm}] \pm \mathrm{SE}}\end{array}$ & $\begin{array}{l}\text { Kraft class, } \\
\text { points] } \pm S E\end{array}$ & $\begin{array}{l}\text { Health condition index, } \\
\text { [points] } \pm S E\end{array}$ & $\begin{array}{c}\text { Branch dieback, } \\
{[\%] \pm \mathrm{SE}}\end{array}$ & $\begin{array}{l}\text { Epicormic shoots, } \\
\text { [points] } \pm \mathrm{SE}\end{array}$ \\
\hline Poliskyi & $31.1 \pm 1.0 \mathrm{a}$ & $2.5 \pm 0.1 \mathrm{a}$ & $2.5 \pm 0.1 \mathrm{a}$ & $15.3 \pm 2.3 \mathrm{a}$ & $0.9 \pm 0.2 \mathrm{ab}$ \\
\hline Western Forest-Steppe & $31.9 \pm 1.6 \mathrm{a}$ & $2.5 \pm 0.1 \mathrm{a}$ & $2.6 \pm 0.1 \mathrm{a}$ & $11.0 \pm 1.8 \mathrm{ab}$ & $1.1 \pm 0.2 \mathrm{ab}$ \\
\hline Right-bank Forest Steppe & $32.2 \pm 1.6 \mathrm{a}$ & $2.6 \pm 0.1 \mathrm{a}$ & $2.7 \pm 0.1 \mathrm{a}$ & $15.3 \pm 1.5 \mathrm{a}$ & $1.7 \pm 0.3 b$ \\
\hline Left-bank Forest Steppe & $33.2 \pm 1.3 \mathrm{a}$ & $2.2 \pm 0.1 \mathrm{a}$ & $2.8 \pm 0.1 \mathrm{a}$ & $14.5 \pm 2.3 \mathrm{a}$ & $0.8 \pm 0.2 \mathrm{a}$ \\
\hline Steppe & $32.2 \pm 1.6 \mathrm{a}$ & $2.4 \pm 0.1 \mathrm{a}$ & $2.6 \pm 0.1 \mathrm{a}$ & $5.5 \pm 1.4 b$ & $0.8 \pm 0.2 \mathrm{a}$ \\
\hline Total sample & $32.1 \pm 0.63$ & $2.4 \pm 0.06$ & $2.6 \pm 0.05$ & $12.3 \pm 0.91$ & $1.0 \pm 0.1$ \\
\hline
\end{tabular}


points each) provenances. The ADB score in Poliskyi and Left-bank Forest Steppe provenances was significantly higher (1.7 points each) comparing to rest provenances (Table 3).

ADB severity score significantly increased over the period 2012-2019 for all provenances except Steppe one.

Collar rot incidence was the lowest (20-25\%) in the Western Forest-Steppe and Right-bank Forest Steppe provenances, and significantly higher (40-45\%) in other provenances. Collar rot severity score varied from 1.2 to 1.8 in different provenances but the difference between them was not significant. Trees colonization by $H$. crenatus was absent in Western Forest-Steppe and Right-bank Forest Steppe provenances. It varied from 5\% (Poliskyi provenance) to $30 \%$ (Steppe provenance) but the differ- ence between them was not significant. Severity score of trees colonization by $H$. crenatus was $0.1-0.3$ points with also insignificant difference (Table 4).

The results obtained allowed pooling the data for all provenances to test the hypothesis about the possible coincidence ash dieback and collar rots, ash dieback and tree colonization by $H$. crenatus, as well as collar rots and tree colonization by $H$. crenatus (Table 5).

The $\chi^{2}$-test proved the coincidence the damage of European ash by ash dieback and collar rots as well as the coincidence the damage of European ash by collar rots and tree colonization by H. crenatus and doesn't support the hypothesis about the coincidence the damage of European ash by ash dieback and tree colonization by H. crenatus (Table 5).

Table 4. Incidence and severity of collar rots and Hylesinus crenatus as the most common damages of European ash in provenance tests (2019).

\begin{tabular}{|c|c|c|c|c|}
\hline Provenance & $\begin{array}{l}\text { Collar rots (CR) } \\
\text { incidence, } \\
{[\%] \pm \mathrm{SE}}\end{array}$ & $\begin{array}{l}\text { severity } \\
{[\text { points] } \pm S E}\end{array}$ & $\begin{array}{l}\text { Hylesinus c } \\
\text { incidence, } \\
{[\%] \pm \mathrm{SE}}\end{array}$ & $\begin{array}{l}\text { severity } \\
\text { [points } \pm \text { SE }\end{array}$ \\
\hline Poliskyi & $45 \pm 11.1 \mathrm{a}$ & $1.8 \pm 0.21 \mathrm{a}$ & $5 \pm 4.9 \mathrm{a}$ & $0.1 \pm 0.05 \mathrm{a}$ \\
\hline Western Forest-Steppe & $20 \pm 8.9 \mathrm{~b}$ & $1.3 \pm 0.23 \mathrm{a}$ & 0 & 0 \\
\hline Right-bank Forest Steppe & $25 \pm 9.7 \mathrm{ab}$ & $1.2 \pm 0.22 \mathrm{a}$ & 0 & 0 \\
\hline Left-bank Forest Steppe & $45 \pm 11.1 \mathrm{a}$ & $1.8 \pm 0.16 \mathrm{a}$ & $15 \pm 8.0 \mathrm{a}$ & $0.2 \pm 0.08 \mathrm{a}$ \\
\hline Steppe & $40 \pm 11.0 \mathrm{a}$ & $1.3 \pm 0.22 \mathrm{a}$ & $30 \pm 10.2 \mathrm{a}$ & $0.3 \pm 0.11 \mathrm{a}$ \\
\hline Total sample & $35 \pm 4.8 \mathrm{a}$ & $1.5 \pm 0.10 \mathrm{a}$ & $10 \pm 3.0 \mathrm{a}$ & $0.1 \pm 0.03 \mathrm{a}$ \\
\hline
\end{tabular}

Note: *Means followed by different letters in each column are significantly different at the $95 \%$ confidence level.

Table 5. Proportion of European ash trees with mixed damage and statistical analysis of correlation between mixed forms of damage in European ash trees (2019).

\begin{tabular}{|c|c|c|c|c|c|c|c|c|c|}
\hline \multirow[b]{2}{*}{ Damage type A } & \multirow[b]{2}{*}{ Damage type B } & \multirow{2}{*}{$\begin{array}{c}\text { Proportion of ash trees with } \\
\text { symptoms of mixed damage, [\%] }\end{array}$} & \multicolumn{4}{|c|}{ Number of inspected trees with the damage } & \multirow[b]{2}{*}{$\mathrm{r}$} & \multirow[b]{2}{*}{$\chi_{\text {fact }}^{2}$} & \multirow[b]{2}{*}{ Conclusion about correlation } \\
\hline & & & $\mathrm{A}$ and $\mathrm{B}$ & A without B & B without $\mathrm{A}$ & neither A nor B & & & \\
\hline$\overline{\mathrm{ADB}}$ & CR & $35 \pm 4.8$ & 35 & 47 & 0 & 18 & 0.34 & 11.8 & proven \\
\hline $\mathrm{ADB}$ & $\mathrm{HC}$ & $10 \pm 3.0$ & 10 & 72 & 0 & 18 & 0.16 & 2.4 & not proven \\
\hline CR & $\mathrm{HC}$ & $8 \pm 2.7$ & 8 & 27 & 2 & 67 & 0.32 & 10.6 & proven \\
\hline
\end{tabular}

Notes: $\chi_{0.05}^{2}=3.84 ; \mathrm{N}=100 ; \mathrm{ADB}-$ ash dieback; $\mathrm{CR}-$ collar rot; HC - Hylesinus crenatus

Table 6. Fungi identified on Fraxinus excelsior stem for different provenances.

\begin{tabular}{|c|c|c|c|c|c|c|}
\hline \multirow[b]{2}{*}{ Fungi } & \multicolumn{6}{|c|}{ Frequency of isolation, [\%] } \\
\hline & Poliskyi & $\begin{array}{c}\text { Western } \\
\text { Forest-Steppe }\end{array}$ & $\begin{array}{c}\text { Right-bank } \\
\text { Forest Steppe }\end{array}$ & $\begin{array}{c}\text { Left-bank } \\
\text { Forest Steppe }\end{array}$ & Steppe & All provenances \\
\hline Alternaria alternata (Fr.) Keissl. & 13.04 & 5.56 & 0.00 & 4.08 & 7.41 & 6.35 \\
\hline Alternaria sp. & 8.70 & 0.00 & 18.18 & 2.04 & 7.41 & 4.76 \\
\hline Armillaria sp. & 4.35 & 0.00 & 9.09 & 6.12 & 3.70 & 3.97 \\
\hline Aureobasidium pullulans (de Bary \& Löwenthal) G. Arnaud & 0.00 & 0.00 & 0.00 & 0.00 & 3.70 & 1.59 \\
\hline Cladosporium sp. & 4.35 & 0.00 & 9.09 & 4.08 & 11.11 & 6.35 \\
\hline Cytosporasp. 15 & 0.00 & 0.00 & 9.09 & 8.16 & 0.00 & 3.97 \\
\hline Didymella macrostoma (Mont.) Qian Chen \& L. Cai & 8.70 & 16.67 & 0.00 & 4.08 & 3.70 & 5.56 \\
\hline Diplodia sp. & 8.70 & 0.00 & 0.00 & 2.04 & 7.41 & 3.97 \\
\hline Epicoccum nigrum Link & 8.70 & 5.56 & 9.09 & 6.12 & 3.70 & 6.35 \\
\hline Fusarium sp. & 8.70 & 5.56 & 0.00 & 6.12 & 0.00 & 4.76 \\
\hline Fusarium avenaceum (Fr.) Sacc. & 0.00 & 16.67 & 0.00 & 0.00 & 7.41 & 4.76 \\
\hline Gliocladium sp. & 13.04 & 0.00 & 0.00 & 0.00 & 14.81 & 5.56 \\
\hline Hymenoscyphus fraxineus (T. Kowalski) Baral, Queloz \& Hosoya & 0.00 & 5.56 & 0.00 & 8.16 & 0.00 & 3.97 \\
\hline Hysterographium fraxini(Pers.) De Not. & 0.00 & 0.00 & 9.09 & 0.00 & 14.81 & 3.97 \\
\hline Phialophora sp. & 0.00 & 5.56 & 0.00 & 4.08 & 0.00 & 2.38 \\
\hline Mortierella sp. & 0.00 & 0.00 & 9.09 & 8.16 & 0.00 & 0.79 \\
\hline Mollisia cinerea (Batsch) P. Karst & 0.00 & 0.00 & 0.00 & 6.12 & 0.00 & 2.38 \\
\hline Penicillium sp. A & 0.00 & 11.11 & 0.00 & 8.16 & 7.41 & 7.94 \\
\hline Penicillium sp. B & 0.00 & 0.00 & 9.09 & 0.00 & 3.70 & 0.79 \\
\hline Pezicula cinnamomea (DC.) Sacc. & 4.35 & 0.00 & 0.00 & 4.08 & 0.00 & 2.38 \\
\hline Phialocephala sp. & 0.00 & 0.00 & 0.00 & 2.04 & 0.00 & 0.79 \\
\hline Sordaria fimicola (Roberge ex Desm.) Ces. \& De Not. & 8.70 & 11.11 & 0.00 & 2.04 & 3.70 & 4.76 \\
\hline Pseudocamarosporium brabeji (Marinc., M.J. Wingf. \& Crous) Crous & 0.00 & 0.00 & 9.09 & 2.04 & 0.00 & 1.59 \\
\hline Sordaria sp. & 0.00 & 11.11 & 0.00 & 4.08 & 0.00 & 3.17 \\
\hline Trichoderma viride Pers. & 4.35 & 0.00 & 0.00 & 0.00 & 0.00 & 1.59 \\
\hline Unidentified sp. 51 & 0.00 & 5.56 & 0.00 & 4.08 & 0.00 & 3.17 \\
\hline Unidentified sp. 58 & 4.35 & 0.00 & 9.09 & 4.08 & 0.00 & 2.38 \\
\hline Unidentified sp. 74 & 4.35 & 0.00 & 9.09 & 2.04 & 2.38 & 2.38 \\
\hline
\end{tabular}


The 25 wood samples from the ash stem yielded a total of 126 fungal isolates ( 23 from provenance Poliskyi (Pol), 18 from provenance Western Forest-Steppe (WF), 11 from provenance Right-bank Forest Steppe (RBFS), 47 from provenance Left-bank Forest Steppe (LBFS) and 27 from provenance Steppe (S) respectively), representing 28 taxons, although only 12 of them could be identified to species level (Table 6).

Only Epicoccum nigrum was isolated from all five provenances. From among all fungi, Penicillium sp. A, Epicoccum nigrum, Cladosporium sp. and $A$. alternata occurred most frequently.

Four of the fungal species were isolated only from a single provenance: Aureobasidium pullulans (Steppe), Mollisia cinerea, Phialocephala sp. (Left-bank Forest Steppe), Trichoderma viride (Poliskyi). Each provenance has a large number of unique species but also a number of shared species. The highest diversity in terms of species richness and Shannon's index was found for the LeftBank Forest Steppe (Fig. 1).

Relatively high species richness was also found for the Poliskyi and Steppe provenances. Lowest species richness was found in the Right-bank Forest Steppe. However, all groups had relatively higher Shannon index values (comparable to samples from Right-bank Forest Steppe). For species richness values, all pairwise comparisons are significantly different $(\mathrm{p}<0.05)$ with Tukey tests except Western Forest-Steppe and Right-bank Forest Steppe; and for Wilcoxon test all are significantly different $(p<0.05)$ except Western Forest-Steppe and Right-bank Forest Steppe. For Shannon index values no pairwise comparisons are significantly different with either the Tukey or Wilcoxon test.

Beta diversity statistics/comparisons among the samples were performed with non-metric multi-dimensional scaling (NMDS) analysis (Fig. 2). Figure 2 shows a map for beta diversity with unweighted unifrac distances among groups.
The highest beta diversity levels are found between Western Forest-Steppe and Right-bank Forest Steppe groups as well as Poliskyi and Right-bank Forest Steppe groups. NMDS picture groups samples into rough clusters corresponding to either their geography (Poliskyi, Western Forest-Steppe, Right-bank Forest Steppe, etc.). A similar pattern can be seen in the plot (Fig. 2). The Right-bank Forest Steppe sample is a diverse set of fungal species in comparison to the Poliskyi and Western Forest-Steppe samples that are only a few close associated fungi with $F$. excelsior. The fungi set from Poliskyi samples groups more closely with Steppe samples than the Western Forest-Steppe, Right-bank Forest Steppe and Left-bank Forest Steppe samples (despite the close geographical proximity of Right-bank Forest Steppe and Left-bank Forest Steppe), thus there seems to be strong influence of provenance on fungal community composition. Left-bank Forest Steppe is the sample with much higher species richness than the others.

Pathogenicity tests. Inoculation with $H$. fraxineus, Cytospora sp. and Diplodia sp. isolates was followed by the development of brownish lesions on all stems of 7-10-year-old plants. The lesions were already obvious after 4 months and significantly longer than control and other isolates. The inoculation trials showed that there were significant differences in the length of necroses $(\mathrm{F}=$ $5.60, \mathrm{p}=0.018$ ) due to the $H$. fraxineus between the three inoculated species. The mean wood necrosis length on the branches of $H$. fraxineus was $25.6 \pm 1.5 \mathrm{~mm}$ (mean \pm standard error) while Cytospora sp. and Diplodia sp. $11.7 \pm 1.1 \mathrm{~mm}$ and $6.7 \pm 1.3 \mathrm{~mm}$, respectively. Moreover, among both the upper and lower lesions, some showed a superficial splitting of the bark. None of the inoculated plants died within 4 months. In re-isolation, Cytospora sp. and Diplodia sp. were obtained from necrotic sections of all inoculated stems of $H$. fraxineus.

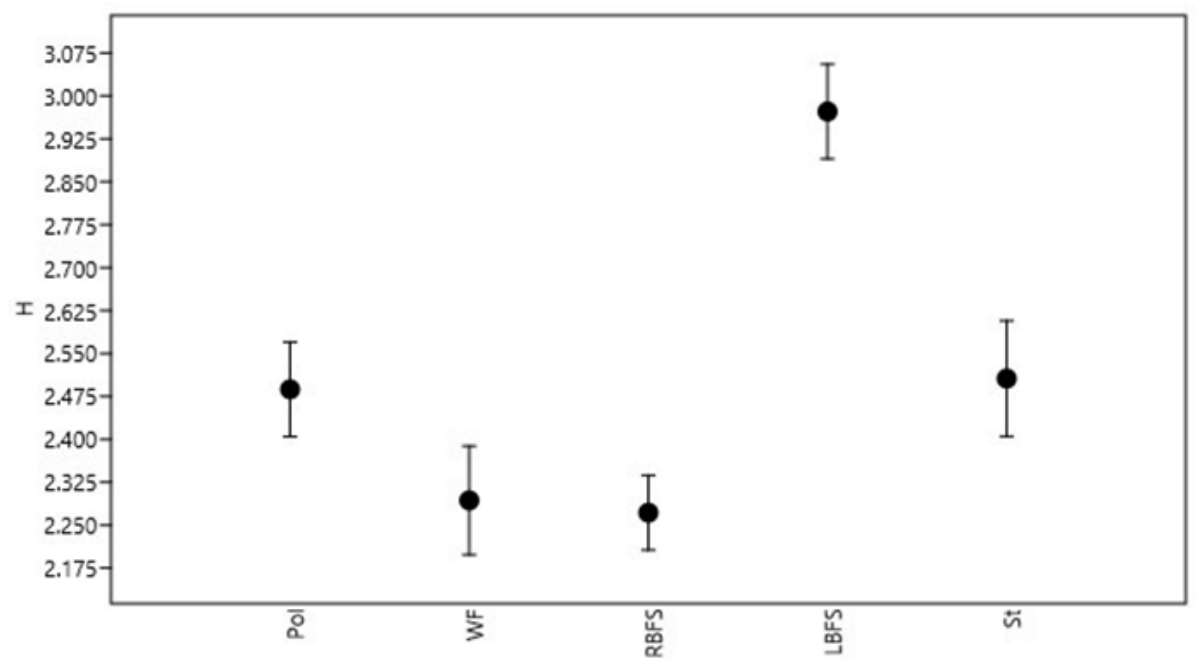

Fig. 1. Box plots of Shannon indices in the five different groups (Pol - Poliskyi, WF - Western Forest Steppe, RBFS - Right-bank Forest Steppe, LBFS - Left-bank Forest Steppe, St - Steppe). 




Fig. 2. NMDS plot of fungal species from Pol - Poliskyi, WF - Western Forest Steppe, RBFS - Right-bank Forest Steppe, LBFS - Left-bank Forest Steppe, St - Steppe.

Legends on the plot corresponds to Alt.alt-Alternaria alternate; Alt-Alternaria sp.; Armil-Armillaria sp; Aurebas -Aureobasidium pullulans; Clad - Cladosporium sp; Cytosp - Cytospora sp. 15; Did macr - Didymella macrostoma; Dipl - Diplodia sp.; Epic - Epicoccum nigrum; Fus Fusarium sp.; Fusaven - Fusarium avenaceum; Gliocl - Gliocladium sp.; Hfrax - Hymenoscyphus fraxineus; Hyster - Hysterographium fraxini; Phial - Phialophora sp; Mort - Mortierella sp.; Molsin - Mollisia cinerea; Pen A - Penicillium sp. A; Pen B - Penicillium sp. B; Pez cin - Pezicula cinnamomea; Phialc - Phialocephala sp.; Sord - Sordaria fimicola; Pseud - Pseudocamarosporium brabeji; Trich - Trichoderma viride; sp 51 Unidentified sp. 51; sp 58 - Unidentified sp. 58; sp 74 - Unidentified sp. 74.

In other cases, the lesion extension was not observed; however, the slight yellowing of leaves was noted after 4 months from inoculation. A. alternata, Didymella macrostoma and Fusarium avenaceum produced no symptoms on stems of plants in experiments although all these species induced brown discoloration (ca. $1 \mathrm{~mm}$ ) around the inoculation points on 7-10-year-old plants. These fungi were re-isolated from the points of inoculation. No lesions developed on any of the control plants and the wounds healed within 4 months after inoculation.

\section{Discussion}

Invasive pathogen Hymenoscyphus fraxineus spread in Europe over 20 years ago (Baral et al. 2014; Gross et al. 2014; Enderle et al. 2015). Its presence in the east of Ukraine, in particular, in the Sumy region, has been confirmed by molecular methods (Davydenko et al. 2013b). In contrast to the western regions (Matsiakh \& Kramarets 2014), the disease in the east develops more slowly and does not often lead to the death of trees (Davydenko \& Meshkova 2017), which may be due to the features of the climate, in particular, with low precipitation (Hlásny et al. 2014; Krakovska et al. 2017). According to another hypothesis, the origin of ash plays a role in the susceptibility of trees to fungal infection (Metzler et al. 2012; Stener 2013; McKinney et al. 2014). Our research attempted to test this hypothesis in the plots of provenance tests of Fraxinus excelsior which were created in 1930 under the leadership of prof. V.M. Andreiev in Sumy region (Davydenko et al. 2013a).

Provenance tests as objects of tree breeding were created primarily to determine the most adapted and productive provenances for specific growing conditions in order to regionalize the supply of seeds for reforestation. The provenances originate from seeds collected from identified stands or regions. However, nowadays they are the only natural models for predicting the impact of climate change consequences (Matyas 1996) as well as to study the tree resistance to new pathogens (Pliura et al. 2011; Metzler et al. 2012). Sometimes, the data from clonal plantations are also considered in the study of resistance (Enderle et al. 2013, 2015). To study the resistance to ash dieback, a provenance trial was established in 2005 in southwest Germany with plots at four sites and eight provenances of Fraxinus excelsior (Enderle et al. 2013, 2015). The intensity of the disease in single trees within the provenances varied constantly between completely unaffected trees and their mortality. The study highlights a high genetic variation in susceptibility and considerable genetic potential for resistance breeding in provenances from southwestern Germany.

In a Danish clonal trial comprising $39 \mathrm{~F}$. excelsior clones established in 2007 with grafts at two sites, mortality was about $40 \%$ in 2013 . The average percentage 
of crown damage increased from $30 \%$ in 2007 to over $60 \%$ in 2013 , with substantial variation among clones (McKinney et al. 2014). In France, only $8 \%$ healthy trees and $88 \%$ of the trees with more than $5 \%$ crown decline were observed. Collar lesions were observed on $33 \%$ of the trees and were present in almost all plots (Husson et al. 2011).

Genetic studies of $F$. excelsior clones in Denmark and Sweden did not reveal any differences among populations in resistance to ADB (McKinney et al. 2014). However, in Lithuania progeny trials established in 2005 at three different sites showed significant differences in resistance to ADB among populations (Pliura et al. 2011). This provides good possibilities for the selection of resistant populations. The health condition of trees was influenced also by site conditions and infection pressure from the surrounding stands.

We compared the health scores of five provenances in 2012 and 2019 by different parameters of growth and health condition. Both in 2012 and in 2019, statistically significant differences in DBH, Kraft class, and health condition index between provenances were not found (Table 1, 2). However, in 2019 compared to 2012, the health condition index significantly increased for all provenances except the Steppe. According to National scale (Davydenko et al. 2019), all provenances in 2012 could be considered as weakened $(1.5<\mathrm{HCI}<2.5)$, and in 2019 they all were severely weakened $(2.5<\mathrm{HCI}<3.5)$.

In 2019, a provenance from Steppe had significantly the lowest branch dieback (average proportion of dry branches in the crowns) (Table 2).

At the same time, ADB incidence was the lowest in the Western Forest-Steppe provenance in 2012 and this parameter did not differ from Steppe in 2019 (Table 3). ADB severity was the highest in Steppe in 2012 but was among the lowest values in 2019.

In 2019 compared to 2012, ADB incidence and severity increased for all provenances except Steppe, however maximal values (1.8 points) were assessed for Poliskyi and Left-bank Forest Steppe provenances (Table 3). So the data obtained do not allow us to draw a conclusion about the different susceptibility of individual ash provenances to the ADB. It may be connected with rather high age of trees (about 90 years old).

In different regions, it was previously found out that collar rots (Langer 2017; Davydenko et al. 2019) and stem colonization with bark beetles (Meshkova \& Borysova 2017) often accompany infestations of ash with ADB. Therefore, in a survey of provenance tests in 2019, the incidence and severity of collar rots and $H$. crenatus was assessed (Table 4). Collar rot presence was revealed in all ash provenances with the lowest values in Western Forest-Steppe and Right-bank Forest Steppe. Differences between provenances in disease severity according to visual assessment were not significant. Trees colonization by $H$. crenatus was absent in Western Forest-Steppe and Right-bank Forest Steppe provenances, and the dif- ferences between other provenances were not significant both by the incidence and severity (Table 4 ).

Statistical analysis supported the conclusion from other regions about the coincidence the damage of European ash by ash dieback and collar rots (Langer 2017; Davydenko et al. 2019) as well as the coincidence the damage of European ash by collar rots and tree colonization by $H$. crenatus (Meshkova \& Borysova 2017) (Table 5). However, the absence of coincidence of ADB and tree colonization by $H$. crenatus may be explained by relatively low incidence of the trees inhabited by $\mathrm{H}$. crenatus and the features of this insect to colonize the lowest part of stem with thick bark (Okolow 1970) while ADB reveals first in the crowns (Skovsgaard et al. 2010). We can suppose that the incidence of other ash bark beetles inhabiting upper stem and branches, especially $H$. fraxini (Panzer 1779) (Pedrosa-Macedo 1979) and H. toranio (Danthoine, 1788) (Graf 1977), can be more closely associated with ADB. However, the assessment of these insects' galleries is possible only after tree felling.

In the present study, the detected fungal communities were largely composed by the generalist saprotrophic and pathogenic fungal taxa (Table 6). Despite that several pathogenic taxa including $H$. fraxineus, Cytospora sp., $H$. fraxini, etc., the fungal community of all provenances showed preference towards saprotrophic species. One to three pathogenic taxa (including A. alternata, E. nigrum, Cytospora sp., $H$. fraxineus and $H$. fraxini) were found in all provenances. Among these, A. alternata and $E$. nigrum are known as opportunistic weak pathogens or even saprophytes with a worldwide distribution. Cytophora sp. is known as the causative agent of Cytospora canker. Other pathogenic fungi were $H$. fraxineus and $H$. fraxini which both are known as a widespread ash dieback-fungi causing massive ash decline. So, the pathogenic fungi were likely the primary cause of disease symptoms. Therefore, we suggest that the fungus $H$. fraxineus is a primary pathogen killing healthy ash tissues. However, later the fungus is losing the competition with other decomposing and saprotrophic fungi being more successful and taking over their domination in dead tissues. So, it explains why necrotic ash shoots usually are colonized by other plant pathogens, endophytes and saprophytes.

Our results for the study of fungal community structure in declining shoots of ash trees in the different geographic provenances as well as inoculation experiment revealed 28 fungal taxa associated with ash trees. Among them, at least three fungal species showed the ability to be pathogens that is the valuable point of this research. Next to Hymenoscyphus fraxineus and Hysterographium fraxini, Cytospora sp. and Diplodia sp. have been considered to be involved in serious decline, in combination with abiotic factors. Our study confirmed previous results published. Przybył (2002), Kowalski \& Łukomska (2005), Lygis et al. (2006) presented data of endophytic fungi on ash branches with the most characteristic fungi 
as we did like Alternaria alternata, Diplodia mutila, Phomopsis sp., Cladosporium cladosporioides, Cytospora ambiens and Phomopsis controversa. Fungi belonging to Phomopsis and Cytospora genera are pathogens of weak trees and are often present in dying shoots (Przybył 2002; Kowalski \& Łukomska 2005).

From this point of view, the knowledge of the distribution of pathogenic fungal species associated with $F$. excelsior suffering from ash-dieback phenomenon can be very useful in forest management and diversity conservation programs.

\section{Conclusion}

Provenance tests of European ash of about 90 years old in Sumy region (Eastern Ukraine) are affected by ash dieback (ADB) caused by pathogen Hymenoscyphus fraxineus for at least 10 years.

For 2012 and 2019 the health condition index, ADB incidence and severity increased for all provenances except the Steppe. However, the data obtained do not allow us to draw a conclusion about the different susceptibility of individual ash provenances to the ADB.

Collar rot was present in all ash provenances with the lowest incidence in provenances from Western ForestSteppe and Right-bank Forest Steppe and the absence of significant differences between provenances in disease severity.

Hylesinus crenatus was not revealed in Western Forest-Steppe and Right-bank Forest Steppe provenances, and the differences between other provenances were not significant both by the incidence and severity.

Fungi isolated from stem of ash trees with varying degrees of decline were identified and the pathogenicity of some of them was determined. Among them, Hymenoscyphus fraxineus, Cytospora sp. and Diplodia sp. induced different necrotic lesions.

The conclusion from other regions about the coincidence the damage of European ash by ash dieback and collar rots (Matsiakh \& Kramarets 2014; Langer 2017) as well as the coincidence the damage of European ash by collar rots and tree colonization by $H$. crenatus (Davydenko et al. 2019) is supported.

\section{References}

Baral, H. O., Queloz, V. K., Hosoya, T. S., 2014:Hymenoscyphus fraxineus, the correct scientific name for the fungus causing ash dieback in Europe. IMA fungus, 5:79-80.

Davydenko, K. V., Meshkova, V. L., Kuznetsova, T. L., 2013a: Spread of Hymenoscyphus pseudoalbidus - the pathogen of ash dieback in the Left-bank Ukraine. Forestry \& Forest Melioration, 123:140-145.
Davydenko, K., Vasaitis, R., Stenlid, J., Menkis, A., 2013b: Fungi in foliage and shoots of Fraxinus excelsior in eastern Ukraine: a first report on Hymenoscyphus pseudoalbidus. Forest Pathology, 43:462-467.

Davydenko K., Meshkova V., 2017: The current situation concerning severity and causes of ash dieback in Ukraine caused by Hymenoscyphus fraxineus. In: Vasaitis R., Enderle R. (eds.): Dieback of European Ash (Fraxinus spp.) - Consequences and Guidelines for Sustainable Management. The Report on European Cooperation in Science \& Technology (COST) Action FP1103 FRAXBACK. SLU - Swedish Institute of Agricultural Sciences, Uppsala, p. 220-227.

Davydenko, K., Borysova, V., Shcherbak, O., Kryshtop, Ye., Meshkova, V., 2019: Situation and perspectives of ash (Fraxinus spp.) in Ukraine: focus on eastern border. Baltic Forestry, 25:193-202.

Enderle, R., Peters, F., Nakou, A., Metzler, B., 2013: Temporal development of ash dieback symptoms and spatial distribution of collar rots in a provenance trial of Fraxinus excelsior. European Journal of Forest Research, 132:865-876.

Enderle, R., Nakou, A., Thomas, K., Metzler, B., 2015: Susceptibility of autochthonous German Fraxinus excelsior clones to Hymenoscyphus pseudoalbidus is genetically determined. Annals of Forest Science, 72:183-193.

Enderle, R., Fussi, B., Lenz, H. D., Langer, G., Nagel, R., Metzler, B., 2017: Ash dieback in Germany: research on disease development, resistance and management options. In: Vasaitis, R., Enderle, R. (eds.): Dieback of European Ash (Fraxinus spp.) - Consequences and Guidelines for Sustainable Management. The Report on European Cooperation in Science \& Technology (COST) Action FP1103 FRAXBACK. SLU - Swedish Institute of Agricultural Sciences, Uppsala, p. 89-105.

Goberville, E., Hautekèete, N. C., Kirby, R. R., Piquot, Y., Luczak, C., Beaugrand, G., 2016: Climate change and the ash dieback crisis. Scientific Reports, 6, 35303.

Graf, P., 1977: A contribution on the biology and control of Hylesinus oleiperda F. (Coleopt., Scolytidae) on olive in the Tadla (Morocco). Zeitschrift fur Angewandte Entomologie, 83:52-62.

Gross, A., Holdenrieder, O., Pautasso, M., Queloz, V., Sieber, T. N., 2014: Hymenoscyphus pseudoalbidus, the causal agent of European ash dieback. Molecular Plant Pathology, 15:5-21.

Hammer, O., Harper, D. A. T., Ryan, P. D., 2001: PAST: paleontological statistics software package for education and data analysis. Palaeontologia Electronica, 4:1-9.

Hlásny, T., Mátyás, C., Seidl, R., Kulla, L., Merganičová, K., Trombik, J. et al., 2014: Climate change increases the drought risk in central European forests: What are the options for adaptation? Lesnícky časopis Forestry Journal, 60:5-18. 
Husson, C., Scala, B., Caël, O., Frey, P., Feau, N., Ioos, R., Marçais, B., 2011: Chalara fraxinea is an invasive pathogen in France. European Journal of Plant Pathology, 130:311-324.

Kowalski T., Łukomska A., 2005: Badania nad zamieraniem jesionu (Fraxinus excelsior L.) w drzewostanach Nadleśnictwa Włoszczowa. Acta Agrobotanica, 59:429-440.

Krakovska, S., Buksha, I., Shvidenko, A., 2017: Climate change scenarios for an assessment of vulnerability of forests in Ukraine in the 21st century. Aerul si Apa. Componente ale Mediului, p. 387-394.

Langer, G., 2017: Collar rots in forests of Northwest Germany affected by ash dieback. Baltic Forestry, 23:4-19.

Lech, P., Żółciak, A., Hildebrand, R., 2020: Occurrence of European Mistletoe (Viscum album L.) on Forest Trees in Poland and Its Dynamics of Spread in the Period 2008-2018. Forests, 11:83.

Lygis, V., Vasiliauskas, R., Larsson, K. H., Stenlid, J., 2005: Wood-inhabiting fungi in stems of Fraxinus excelsior in declining ash stands of northern Lithuania, with particular reference to Armillaria cepistipes. Scandinavian Journal of Forest Research, 20:337-346.

Matsiakh, I. P., Kramarets, V. O., 2014: Declining of Common Ash (Fraxinus excelsior L.) in Western Ukraine. Scientific Herald of National Forest Technical University of Ukraine, 24.7: 67-74.

Matyas, C., 1996: Climatic adaptation of trees: rediscovering provenance tests. Euphytica, 92:45-54.

McKinney, L. V., Nielsen, L. R., Collinge, D. B., Thomsen, I. M., Hansen, J. K, Kjær, E. D., 2014:Theash dieback crisis: genetic variation in resistance can prove a long-term solution. Plant Pathology, 63:485-499.
Meshkova, V. L., Borysova, V. L., 2017: Damage causes of European ash in the permanent sampling plots in Kharkiv region. Forestry and Forest Melioration, 131:179-186.

Metzler, B., Enderle, R., Karopka, M., Topfner, K., Aldinger, E., 2012: Development of ash dieback in a provenance trial on different sites in southern Germany. Allgemeine Forst- und Jagdzeitumg, 183:168180.

Okolow, C., 1970: Hylesinus crenatus: its morphology, biology, enemies and economic importance. Folia Forestalia Polonica, 16:171-200.

Pedrosa-Macedo, J. H., 1979: Zur Bionomie, Ökologie und Ethologie des Eschenbastkäfers, Leperisinus varius F. (Col., Scolytidae). Zeitschrift für Angewandte Entomologie, 88:188-204.

Pliura, A., Lygis, V., Suchockas, V., Bartkevicius, E., 2011: Performance of twenty-four European Fraxinus excelsior populations in three Lithuanian progeny trials with a special emphasis on resistance to Chalara fraxinea. Baltic Forestry, 17:17-34.

Przybył, K., 2002: Fungi associated with necrotic apical parts of Fraxinus excelsior shoots. Forest Pathology, 32:387-394.

Queloz, V., Grünig, C. R., Berndt, R., Kowalski, T., Sieber, T. N., Holdenrieder, O., 2011: Cryptic speciation in Hymenoscyphus albidus. Forest Pathology, 41:133-142.

Skovsgaard, J. P., Thomsen, I. M., Skovgaard, I. M., Martinussen, T., 2010: Associations among symptoms of dieback in even-aged stands of ash (Fraxinus excelsior L.). Forest Pathology, 40:7-18.

Stener, L. G., 2013: Clonal differences in susceptibility to the dieback of Fraxinus excelsior in southern Sweden. Scandinavian Journal of Forest Research, 28:205-216. 